\title{
LEGALITAS RIWAYAT ASBĀB AL-NUZŪL Telaah historis konteks turunya ayat al-Quran
}

\author{
Abd. Kholid \\ Dosen Tafsir pada Fakultas Ushuluddin IAIN Sunan Ampel \\ Surabaya \\ e-mail: abd.kholiq@gmail.com
}

\begin{abstract}
Asbāb al-Nuzūl (occasions of revelation) is event becoming background send down the verse of the Quran. Scope solution of Asbāb al-Nuzūl only relating to event degrading of the verse of the Quran especially in event relation and word expression, that include texts or materials. This science is very importance in order to interpret the verses of the Quran. This is not mean that it is to generalize interpretation entire verses of the Quran with Asbāb al-Nuzūl, because there is not all verses of the Quran send down with Asbāb al-Nuzūl. But, for the verses of the Quran have Asbāb al-Nuzūl, that its interpretation is more authentic.
\end{abstract}

Abstrak: Asbāb al-Nuzūl adalah peristiwa yang menjadi latar belakang turunnya ayat al-Quran. Ruang lingkup pembahasan Asbāb al-Nuzūl hanya berkaitan dengan peristiwa diturunkannya ayat al-Quran terutama dalam hubungan peristiwa dan ungkapan kata, baik teks ayat, maupun redaksi ayat. Ilmu ini sangat penting dalam rangka menafsirkan ayat-ayat al-Quran. Hal ini bukan berarti menggeneralisasi keharusan menafsirkan seluruh ayat al-Quran dengan Asbāb al-Nuzūl, karena tidak semua ayat al-Quran turun disertai dengan Asbāb al-Nuzūl. Akan tetapi bagi ayat-ayat al-Quran yang memiliki Asbāb alNuzūl, maka penafsirannya akan lebih otentik.

Keywords: asbāb al-nuzūl, 'ulūm al-Qur'ān, ilmu Ma'ānī dan Ilmu Bayān, Nabi Muhammad, dan sahabat. 


\section{A. Pendahuluan}

Al-Quran adalah kitab suci kaum muslimin dan menjadi sumber ajaran Islam yang pertama dan utama yang harus mereka imani dan aplikasikan dalam kehidupan mereka agar memperoleh kebaikan dunia dan akhirat. Karena itu, kaum muslimin tidak hanya mempelajari dan memahami isi dan pesan-pesannya, tetapi berupaya semaksimal mungkin untuk menjaga otentitasnya. Upaya itu telah mereka laksanakan sejak turunnya al-Quran hingga saat ini.

Dilihat dari dimensi sejarah, ayat-ayat al-Quran dibagi menjadi dua bagian: Pertama, ayat-ayat al-Quran yang turun tanpa didahului oleh sesuatu sebab, peristiwa atau kejadian tertentu yang melatar belakanginya, hal ini seperti ayat-ayat hukum atau tata cara pergaulan yang memang diturunkan sebagai petunjuk bagi kaum muslimin. Kedua, ayat-ayat yang turun karena adanya sebab atau kejadian atau peristiwa yang melatar belakangi turunnya ayat. ${ }^{1}$

Adanya sebagian ayat al-Quran yang turun karena adanya sebab, peristiwa atau kejadian menunjukkan adanya hubungan dialektika antara naș (teks) dan realitas. Asbāb al-nuzūl memberikan materi baru bagaimana peran teks dalam merespon realitas yang melingkupinya. Teks juga menjelaskan bagaimana ayat atau sejumlah ayat diturunkan ketika ada satu peristiwa khusus yang mengharuskan munculnya teks tersebut. Tidak sedikit ayat-ayat yang diturunkan dengan adanya sebab eksternal, sehingga dalam memahami makna teks dituntut adanya pengetahuan awal tentang realitas yang memunculkan teks-teks tersebut. ${ }^{2}$

Al-Quran yang diturunkan selama lebih dari dua puluh tahun secara berangsur-angsur merupakan jawaban langsung terhadap problematika yang muncul saat itu. Sebagai kitab petunjuk bagi umat manusia al-Quran hanya memberikan 
prinsip-prinsip dasar dan umum, sehingga al-Quran mampu menjawab problem yang muncul pada masa pewahyuan. Peristiwa-peristiwa yang melatar belakangi pewahyuan tersebut dapat dijadikan pedoman untuk menemukan prinsip-prinsip umum yang terkandung dalam ayat-ayat al-Quran. Namun demikian setiap mufassir tidak harus mencari sebab turun setiap ayat, karena tidak semua ayat al-Quran diturunkan karena timbulnya suatu peristiwa dan kejadian sebagaimana dijelaskan di atas. $^{3}$

Di antara sekian banyak aspek yang banyak memberikan peran dalam menggali dan memahami makna-makna ayat alQuran ialah mengetahui sebab turunnya. Pembahasan dimensi sejarah, kisah-kisah al-Quran ini tidak dimaksudkan untuk mempelajari makna historis kisah-kisah al-Quran, tetapi mencoba mengungkapkan nilai historis sejarah turunnya suatu ayat. ${ }^{4}$ Permasalahan yang timbul dalam hal ini adalah adanya perselisihan pendapat para mufassir tentang ketegasan redaksi riwayat yang menunjukkan sebab nuzul ayat, disamping terdapatnya berbagai riwayat asbab nuzul yang menjadi sebab turunnya ayat-ayat tertentu yang saling kontradiktif. Makalah ini akan mengkaji bagaimana peran kajian sejarah yang dilakukan para mufassirin dalam mencari solusi permasalahan tersebut.

\section{B. Pengertian Asbāb al-Nuzūl}

Menurut bahasa asbāb al-nuzūl berasal dari kata asbab, jamak dari lafal sabab yang berarti tali, secara terminologi lafaz ini bemakna segala sesuatu yang menjadi sebab sampainya pada sesuatu hal yang lain. ${ }^{5}$ Makna tersebut sama dengan apa yang disebutkan dalam kitab Lisān al-'Arab, akan tetapi dalam kitab tersebut ditambahkan bahwa lafaz ini berasal dari bahasa Hużail. Kemudian para pakar bahasa mengartikan lafaz ini sebagai suatu hal yang merupakan sebab terhadap sesuatu yang diminta. ${ }^{6}$ Dalam tataran Ușūl al-Fiqh, sabab berarti hal yang 
menjadi sebab adanya hukum sesuatu, akan tetapi tidak berpengaruh terhadap sesuatu tersebut. ${ }^{7}$ Dalam ranah Ușūl alFiqh, pembahasan masalah ini meluas sampai ke masalah 'illah yang kemudian akan berlanjut ke qiyās. sedangkan, al-Nuzūl adalah bentuk infinitif (mașdar) dari nazala yang artinya antara lain: inhadara (jatuhnya sesuatu dari ketinggian), halla (terjadinya sesuatu). ${ }^{8}$ Dalam kitab Asbāb al-Nuzūl karya Imām al-Wahīīi menyebutkan bahwa kata al-nuzūl biasanya digunakan untuk sebab munculnya al-Quran. Sebab munculnya hadis lazimnya menggunakan istilah Asbāb al-Wurūd, sedangkan istilah Asbāb al-Nuzūl hanya digunakan untuk al-Quran saja. ${ }^{9}$

Dari pengertian di atas, yang dimaksud dengan Asbāb alNuzūl adalah persoalan-persoalan yang menjadi penyebab turunnya ayat al-Quran pada kondisi tertentu, yang mana turunnya ayat tersebut menjadi solusi atau penjelasan (hukum) bagi persoalan tersebut. Atau sebagaimana didefinisikan Șubhī Șāliḥ:

$$
\text { ما نزل الاية او الايات بسببه متضمنة له او محيبة عنه مبينة لحكمه زمن وقوعه }
$$

"Sesuatu yang dengan sebabnya turun sesuatu ayat atau beberapa ayat yang mengandung sebab itu, atau memberi jawaban tehadap sebab itu, atau menerangkan hukumnya pada masa terjadinya sebab itu" 10

Dari definisi-definisi di atas, Asbāb al-Nuzūl berkisar pada terjadinya suatu peristiwa yang kemudian menyebabkan turunnya sebuah ayat untuk menjelaskan peristiwa tesebut beserta hukumnya dan adanya pertanyaan yang dihadapkan kepada nabi sehingga turun sebuah ayat untuk menjelaskan hukumnya. Namun tidak semua ayat-ayat al-Quran diturunkan karena adanya suatu peristiwa atau pertanyaan kepada Rasulullah, terdapat juga ayat-ayat al-Quran turun sebagai permulaan tanpa adanya sebab yang menyertainya, seperti ayatayat yang menjelaskan tentang aqidah keimanan, kewajiban 
Islam dan syariat-syariat Allah dalam kehidupan pribadi dan sosial. Dalam hal ini al-Ja'barī berkata :

$$
\text { نزل القرآن على قسمين قسم نزل ابتدآء وقسم نزل عقب واقعة او سؤال }
$$

"Al-Quran turun dalam dua kategori: ada yang turun sebagai permulaan dan ada yang turun akibat adanya peristiwa atau pertayaaan" 11

Hal ini dapat digambarkan bahwa persoalan tersebut terjadi di zaman Rasulullah, bahkan dikemukakan dihadapan Rasulullah kemudian Allah menurunkan ayat al-Quran sebagai penjelas dan jawaban atas persoalan tersebut. ${ }^{12}$ Dengan demikian munculnya Asbāb al-Nuzūl disebabkan karena: (1) adanya suatu peristiwa yang terjadi pada masa nabi baik berupa adanya perbedaan pendapat, ${ }^{13}$ perbuatan salah, ${ }^{14}$ atau adanya keinginan-keinginan tertentu, ${ }^{15}$ baik peristiwa tersebut terkait dengan problematika masa lalu, ${ }^{16}$ ketika itu ${ }^{17}$ atau masa yang akan datang. ${ }^{18}$ Dengan peristiwa itu kemudian turun satu atau beberapa ayat yang menjelaskan hal-hal terkait dengan peristiwa tersebut. (2) Adanya pertanyaan yang ditujukan kepada nabi lalu turun ayat atau beberapa ayat al-Quran sebagai jawaban atau penjelasan hukum atas pertanyaaan tersebut. ${ }^{19}$

Makna "pada kondisi tertentu" adalah situasi atau kondisi yang menjadi latar belakang turunnya al-Quran, juga menjadi latar proses kejadian yang menjadi Asbāb al-Nuzūl ayat tersebut. Baik ayat tersebut turun langsung sesudah sababnya ataupun berselang beberapa lama. Sebagaimana kejadian ketika salah seorang Quraysh bertanya kepada Rasulullah tentang ruh, așhāb al-kahfi, dan Żū al-Qarnain. Ketika itu Rasulullah bersabda: "Besok saya akan memberi jawaban kepadamu", namun kemudian wahyu yang berisi jawaban atas pertanyaan kaum Quraish tersebut tidak segera turun disebabkan rasulullah tidak berucap "Insyā Allāh", bahkan Ibn Isḥāq meriwayatkan bahwa wahyu tidak turun hingga 15 hari sesudah pertanyaan 
kaum Quraisy tersebut hingga Rasulullah merasa sedih. Kemudian Allah menurunkan ayat:

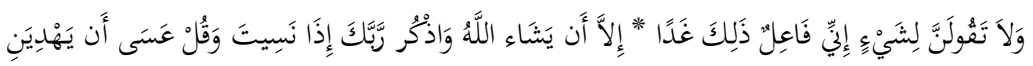

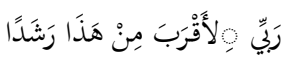

Dan jangan sekali-kali kamu mengatakan tentang sesuatu: "Sesungguhnya aku akan mengerjakan ini besok pagi." Kecuali (dengan menyebut): "Insya Allah", dan ingatlah kepada Tuhanmu jika kamu lupa dan katakanlah: "Mudahmudahan Tuhanku akan memberiku petunjuk kepada yang lebih dekat kebenarannya dari pada ini" (QS. al-Kahfi [18]: 23-24). 20

Dengan batasan ini maka ayat-ayat yang turun tidak pada waktu terjadinya suatu peristiwa tidaklah terkait dengan Asbāb al-Nuzūl seperti ayat-ayat yang turun tentang kisah nabi-nabi terdahulu dan yang menerangkan tentang peristiwa masa lalu dan yang ghaib pada masa akan datang. Dengan demikian maka pendapat al-Wahidī yang menyatakan bahwa sebab turunnya surat al-Fīl adalah kisah penyerbuan pasukan Habasyah tidaklah benar karena surat al-Fīl termasuk berita-berita tentang kejadian masa lalu seperti halnya cerita Nabi Nūh, kaum 'Ad, kaum Śamūd, dan lain sebagainya. ${ }^{21}$

\section{Urgensi dan manfaat Asbāb al-Nuzūl}

Mengetahui Asbāb al-Nuzūl sangatlah penting terutama berkaitan dengan penafsiran al-Quran, oleh karenanya para ulama menjadikan Asbāb al-Nuzūl sebagai ilmu yang harus dikuasai bagi seorang yang akan menafsirkan al-Quran, bahkan al-Suyūt\}ī menjadikan ilmu ini sebagai ilmu yang wajib dipelajari bagi seorang yang ingin mengetahui isi kandungan alQuran. ${ }^{22}$ Urgensi Asbāb al-Nuzūl dapat kita lihat dari pernyataan Ibn Taymiyah:

$$
\text { معرفة سباب النزول يعين على فهم الاية فأن العلم بالسبب يورث العلم بالمسبب }
$$


"Mengetahui sebab nuzūl akan membantu dalam memahami ayat, karena mengetahui sebab menimbulkan pengetahuan tentang musabbab (akibat)." 23

Al-Wāḥidī menyatakan:

$$
\text { لايمكن معرفة تفسير الآية دون الوقوف على قصتها وبيان نزولها }
$$

"Tidak mungkin mungkin mengetahui tafsir ayat tanpa mengetahui sejarah penjelasan sebab turunnya." 24

Dalam kitab Asbāb al-Nuzūl, al-Wāḥidī mengutip pendapat al-Shātibī bahwasanya memahami Asbāb al-Nuzūl merupakan keharusan bagi siapa saja yang hendak mempelajari ulūm alQur'ān. Hal ini disebabkan karena dua hal. Pertama, Asbāb alNuzūl adalah salah satu hal yang sangat diperlukan dalam ilmu Ma'ānī dan Ilmu Bayān untuk mengetahui kemukjizatan tata bahasa al-Quran terutama mengetahui maksud kata-kata berbahasa Arab. Karena hanya dengan Asbāb al-Nuzūl keadaan di mana sebuah kata itu muncul (متضضيات الأحوال) dapat diketahui.25 Kedua, menafsirkan ayat al-Quran tanpa Asbāb al-Nuzūl akan menimbulkan masalah, karena penafsiran tersebut terkesan global ( إنمْكِل ) yang pada akhirnya menimbulkan perbedaan yang berlanjut pada perselisihan. ${ }^{26}$

Peran Asbāb al-Nuzūl dalam menjaga validitas tafsir alQuran juga nampak dalam riwayat tentang kesulitan Marwan bin al-Hakam dalam memahami ayat:

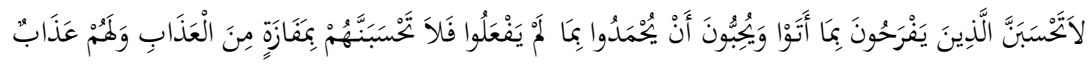

"Janganlah sekali-kali kamu menyangka bahwa orangorang yang gembira dengan apa yang telah mereka kerjakan dan mereka suka dipuji dengan perbuatan yang belum mereka kerjakan, janganlah kamu menyangka bahwa mereka terlepas dari siksa. (QS. Ali 'Imrān [3]: 188). 
Marwān menyuruh pembantunya Rafi' untuk bertanya kepada Ibn 'Abbās terkait dengan ayat ini: "Pergilah ke Ibn 'Abbās dan katakan: "Kalau setiap orang yang suka atas sesuatu yang diperbuat serta suka dipuji atas sesuatu yang tidak diperbuat itu disiksa, maka kita semua akan disiksa", Ibn 'Abbās lalu menjelaskan, namun orang itu tidak paham. Kemudian Ibn 'Abbās berkata: "Sesungguhnya ayat ini turun pada ahli Kitab (Yahudi) ketika mereka ditanya oleh Nabi, mereka menyembunyikan sesuatu kepada Nabi. Bahkan mereka mengatakan yang lain. Mereka mengira bahwa mereka telah mengabarkan sesuatu yang ditanyakan oleh nabi, dan mereka mengharapkan pujian atas hal tersebut. Maka turunlah ayat tersebut. ${ }^{27}$ Riwayat ini menunjukkan betapa urgennya Asbāb alNuzūl dalam memahami ayat-ayat al-Quran.

Tentang faedah mengetahui Asbāb al-Nuzūl ada sebagian orang yang beranggapan bahwa Asbāb al-Nuzūl tidak memiliki faedah apapun karena ia hanya berfungsi sebagai sejarah, bahkan bukan merupakan kebutuhan pokok bagi orang yang hendak menafsirkan ayat al-Quran. ${ }^{28}$ Tentang Pendapat ini banyak ulama' yang menolak, hal ini dikarenakan banyak ayatayat al-Quran yang sulit dipahami kecuali dengan Asbāb alNuzūl. Sehingga, menafsirkan dengan Asbāb al-Nuzūl adalah sebuah keniscayaan untuk sebagian ayat-ayat al-Quran.

Imām al-Zarqanī mencatat ada tujuh faedah mengetahui Asbāb al-Nuzūl, yaitu: Pertama, mengetahui maksud/hikmah turunnya ayat. Hal ini akan sangat bermanfaat baik bagi orang yang beriman maupun yang tidak. Bagi orang yang telah beriman, hal ini akan menambah iman mereka dan meningkatkan semangat mereka dalam mengamalkan hukumhukum Allah. Sedangkan bagi orang yang tidak beriman, hal ini akan mendorong mereka kepada iman jika mereka mau untuk bersikap objektif sehingga tahu akan komitmen syariah Islam 
terhadap kemaslahatan manusia. Hal ini sebagaimana tahapan tentang pengharaman khamr. ${ }^{29}$ Kedua, membantu dan memudahkan untuk memahami ayat al-Quran. Sebagai contoh adalah kesulitan yang dialami Marwan ibn al-Hakam dalam memahami surat Ali 'Imrān ayat; 188 sebagaimana di atas. ${ }^{30}$ Ketiga, menghindari kesamaran al-Hasyr. ${ }^{31}$ Sebagai contoh adalah surat al-An'ām ayat 145 :

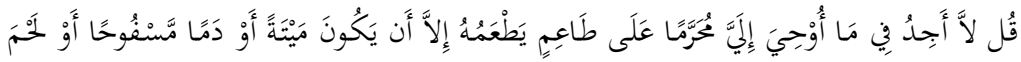

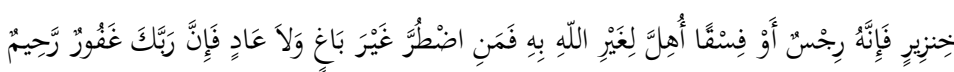

Katakanlah: "Tiadalah aku peroleh dalam wahyu yang diwahyukan kepadaku, sesuatu yang diharamkan bagi orang yang hendak memakannya, kecuali kalau makanan itu bangkai, atau darah yang mengalir atau daging babi karena sesungguhnya semua itu kotor - atau binatang yang disembelih atas nama selain Allah. Barangsiapa yang dalam keadaan terpaksa, sedang dia tidak menginginkannya dan tidak (pula) melampaui batas, maka sesungguhnya Tuhanmu Maha Pengampun lagi Maha Penyayang.” (QS. al-An‘ām [6]: 145).

Menurut Imām al-Syāfi'ī ayat ini tidak dimaksudkan sebagai al-Hasyr ${ }^{32}$ sebagaimana dijelaskan dalam sabāb nuzūlnya. Namun, ayat ini turun ditujukan untuk orang-orang kafir yang membangkang dengan mengharamkan apa-apa yang dihalalkan Allah dan menghalalkan apa-apa yang diharamkanNya sebagai sikap keras kepala dan tantangan kepada Allah dan Rasul-Nya. Kemudian Allah menurunkan ayat ini sebagai counter terhadap sikap keras kepala orang-orang kafir tersebut. ${ }^{33}$

Menurut Imām al-Ḥarāmain pendapat al-Syāfi'ī ini merupakan pendapat yang amat bagus, menurutnya jika alSyāfi'ī tidak mengemukan demikian tentu ia tidak diperbolehkan 
berbeda pendapat dengan Imām Malik dalam meringkas hukum haram terhadap apa yang disebutkan dalam ayat tersebut. ${ }^{34}$

Keempat, men-takhșiș (membatasi) hukum dengan sabab yang terjadi. Demikian ini bagi ulama yang berpendapat bahwa kesimpulan itu diambil dari khususnya sabab bukan dari keumuman lafaz (العبرة بعموم اللفظ لا بخصوص السبب), dalam hal ini pengetahuan tentang Asbāb al-Nuzūl mutlak dibutuhkan. Sebagai contoh adalah upaya dalam memahami surat alMujadilah ayat 1-3 dimana sebab nuzulnya adalah kasus zihar yang dilakukan oleh Aus bin Șāmit kepada isterinya, yaitu Khaulah binti Śa'labah.

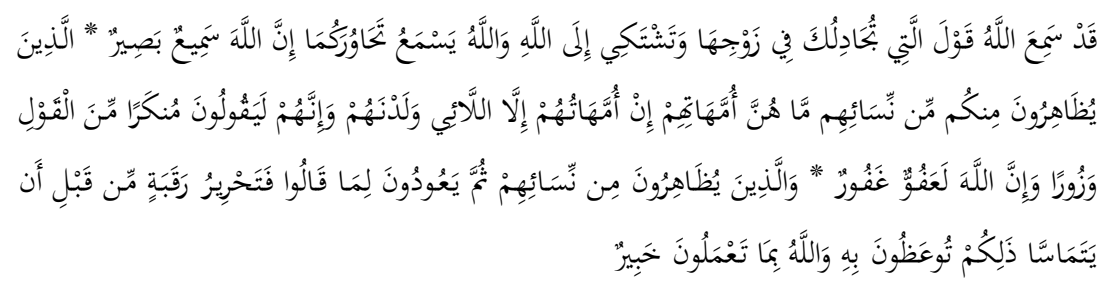

"Sesungguhnya Allah telah mendengar perkataan wanita yang mengajukan gugatan kepada kamu tentang suaminya, dan mengadukan (halnya) kepada Allah. Dan Allah mendengar soal jawab antara kamu berdua. Sesungguhnya Allah Maha Mendengar lagi Maha Melihat. Orang-orang yang menzhihar isterinya di antara kamu, (menganggap isterinya sebagai ibunya, padahal) tiadalah isteri mereka itu ibu mereka. Ibu-ibu mereka tidak lain hanyalah wanita yang melahirkan mereka. Dan sesungguhnya mereka sungguh-sungguh mengucapkan suatu perkataan mungkar dan dusta. Dan sesungguhnya Allah Maha Pemaaf lagi Maha Pengampun. Orang-orang yang menzhihar isteri mereka, kemudian mereka hendak menarik kembali apa yang mereka ucapkan, maka (wajib atasnya) memerdekakan seorang budak sebelum kedua suami isteri itu bercampur. Demikianlah yang diajarkan kepada kamu, 
dan Allah Maha Mengetahui apa yang kamu kerjakan" (QS. al-Mujādalah [58]: 1-3).

Menurut ulama yang mengikuti kaidah di atas, maka hukum yang terkandung dalam ayat ini adalah khusus bagi Aus bin Șāmit dan Khaulah binti S|a'labah saja. Sedangkan bagi orang lain yang juga melakukan zihar kepada isterinya, maka hukumnya di-qiyas-kan kepada mereka berdua. 35

Kelima, menggunakan Asbāb al-Nuzūl dalam takhșiṣ. Sebagai contoh adalah Abū $\mathrm{H}$ \{anīfah yang mengartikan hadis Nabi yang berbunyi : "الولد للفراش" (seorang anak itu milik pemilik kasur) dengan arti zahirnya, sehingga beliau melakukan kesalahan karena tidak memperhatikan sabāb nuzūl-nya. Asbāb al-Nuzūl lafaz tersebut adalah: pada suatu hari 'Utbah bin Abī Waqāṣ berwasiat pada saudaranya Sa'ad bin Abī Waqāṣ supaya mengambil anak yang dilahirkan Zam'ah, karena anak itu darinya. Ketika terjadi Fatḥu al-Makkah Sa'ad bin Abì Waqaș mengambil anak tersebut, dia berkata: "Dia anak saudaraku, saudaraku telah mewasiatkannya kepadaku”. Kemudian 'Abdun anak Zam'ah berdiri lalu berkata: "Dia saudaraku, dia anak yang dilahirkan (dari benih) bapakku, yakni dilahirkan di atas kasurnya." Kemudian hal ini sampai pada Rasulullah. Sa'ad berkata: "Ya Rasulullah, dia anak saudaraku, sungguh saudaraku telah mewasiatkan aku (untuk mengambilnya)". Kemudian 'Abdun anak Zam'ah berkata: "Dia saudaraku, dia dilahirkan (dari benih) bapakku, dia dilahirkan di atas kasurnya." Kemudian Rasulullah bersabda: "Anak itu milik pemilik kasur dan bagi pezina akan mendapatkan batu (dirajam) (الولد للفراش وللعاهر (الحجر)." Kemudian Rasulullah bersabda pada Saudah binti Zam'ah: "Saudah, tutupilah aku darinya." Sesudah mengetahui kecacatan/kesamaran 'Utbah (dengan Zam'ah), Rasulullah tidak pernah melihatnya (Zam'ah) sampai meninggal dunia. ${ }^{36}$ Dari Asbāb al-Nuzūl di atas dapat dipahami bahwa hadis yang 
menyatakan bahwa seorang anak itu milik șāhib al-Firāṣ (pemilik kasur) tidak bersifat umum. Akan tetapi hal itu dikhususkan untuk anak Zam'ah saja.

Keenam, mengetahui dengan jelas nama orang terkait Asbāb al-Nuzūl sebuah ayat, sehingga ayat tersebut mudah difahami. Sebagai contoh Marwān mengira bahwa surat al-Aḥqāf ayat 17 diturunkan terkait dengan kisah 'Abd al-Raḥmān bin Abū Bakar. 'Aishah membantah: "Itu tidak benar", kemudian 'Aishah menjelaskan sebab turunnya ayat sebagaimana diriwayatkan al-Bukhārī. ${ }^{37}$ Ketujuh, Memudahkan untuk dihafal dan difahami serta lebih mengokohkan hati orang yang mendengarkan ayat al-Quran jika ia mengetahui sebab turunnya. 38

\section{Legalitas riwayat Asbāb al-Nuzūl}

Pada dasarnya jumhur ulama berpendapat bahwa legalitas Asbāb al-Nuzūl hanya dapat ditetapkan dengan ja1an riwayat dan mendengar langsung dari para sahabat, karena mereka adalah orang-orang yang terlibat langsung dan menyaksikan turunnya wahyu dan mereka mengerti betul sebab-sebab turunnya suatu ayat kepada nabi.

Ibn Sirīn berkata, "Aku bertanya kepada 'Ābidah tentang suatu ayat", kemudian ia berkata: "Bertakwalah kepada Allah dan berkatalah dengan benar. Ketahuilah, bahwa orang-orang yang mengetahui sebab-sebab diturunkannya ayat al-Quran sangat langka."39 Berkaitan dengan ini, al-Wahịīī berkata:

$$
\text { عن علمها وجدوا في الطلب اسباب نزول الكتاب الا بالرواية والسماع من شاهدوا التنزيل ووقفوا على الاسباب وبكثوا }
$$

"Tidakhalal berpendapat mengenai asbāb al-Nuzūl ayat alQuran kecuali dengan berdasarkan pada riwayat atau mendengar langsung dari orang-orang yang menyaksikan turunnya, mengetahui sebab-sebabnya, membahas tentang 
pengertiannya dan bersunguh-sungguh dalam mencarinya."

Al-Wāhịīī telah menentang ulama-ulama zamannya atas kecerobohan mereka terhadap riwayat Asbāb al-Nuzūl. Bahkan ia menuduh mereka pendusta dan mengingatkan mereka akan ancaman berat, dengan mengatakan, "Sekarang setiap orang suka mengada-ngada dan berbuat dusta: ia menempatkan kedudukannya dalam kebodohan, tanpa memikirkan acaman berat bagi orang yang tidak mengetahui sebab turunnya ayat." 40

Dari sini tampak jelas bahwa periwayatan mengenai $A s b a \bar{b}$ al-Nuzūl tidak dapat diterima kecuali dari periwayatan orang yang menyaksikan peristiwa turunnya al-Quran, menjadi saksi hidup peristiwa yang dijadikan sebagai Asbāb al-Nuzūl, dan berusaha mengetahuinya dengan sungguh-sungguh.41 Oleh karena itu, semua Asbāb al-Nuzūl yang diriwayatkan oleh setiap sahabat dapat diterima walaupun tidak ada riwayat lain yang menguatkannya. Bahkan selama riwayat tersebut tidak memasuki ranah ijtihad, hukumnya dapat dianggap marfu' 42 kepada Rasulullah. Jikalau riwayat Asbāb al-Nuzūl mursal, artinya hanya disandarkan pada para sahabat dan periwayatnnya selesai di tabi'in, maka hanya bisa diterima jika ada hadis mursal lain yang menguatkan. Adapun contoh ahli tafsir dari tabi'in yang menyandarkan periwayatannya kepada sahabat adalah Mujāhid, 'Ikrimah, dan Sa'īd bin Zubair. ${ }^{43}$

Menurut Nasr Ḥāmid Abū Zayd menyandarkan pengetahuan Asbāb al-Nuzūl hanya pada sisi periwayatan tidaklah mencukupi, karena periwayatan Asbāb al-Nuzūl mulai muncul pada masa tābi'în. Sedang pada masa sahabat belum diperlukan adanya Asbāb al-Nuzūl utuk memahami ayat-ayat alQuran. Kebutuhan akan adanya Asbāb al-Nuzūl muncul ketika pada masa tabi'in mengalami kesulitan dalam mengungkap makna yang terkandung dalam suatu ayat, sehingga intervensi 
dalam periwayatan sulit dihindari, untuk itu pengetahuan tentang Asbāb al-Nuzūl masih ada ruang ijtihad.

Menurut Nasr cara mengetahui Asbāb al-Nuzūl dengan ijtihad dilakukan dengan bersandar pada sejumlah unsur dan tanda-tanda internal dan eksternal dalam suatu ayat. Asbāb alNuzūl hanyalah konteks sosial bagi suatu ayat sehingga sebabsebab turunnya ayat dapat dicari dari dalam dan luar teks. ${ }^{4}$

Ijtihad sebagai cara untuk menentukan Asbāb al-Nuzūl sebenarnya telah dilakukan oleh Imām Shāfi'ì seorang atba' altābi'īn, dalam menjelaskan Asbāb al-Nuzūl surat al-An'ām ayat 145 yang secara lahiriah menyebutkan makanan yang dihalalkan Allah adalah bangkai, darah yang mengalir, daging babi dan hewan yang disembelih tidak karena Allah. Ayat ini, menurut Imām Syāfi'ī bukan merupakan pembatasan sesuatu yang diharamkan Allah sebagaimana pendapat Imām Malik, tetapi ayat ini turun berkaitan denagn situasi orang-orang kafir yang mengharamkan apa yang dihalalkan Allah dan menghalalkan apa yang diharamkan Allah. Pendapat Imām Shāfi'ì juga didasarkan pada urutan turunnya ayat dalam pelarangan khusus soal makanan adalah sebagai berikut: alAn'ām: 145, al-Naḥl: 115-116, al-Baqarah: 172-173, kemudian al-Mā'idah: 4. Ayat yang membatasi makanan yang haram adalah ayat yang turun terakhir, yaitu al-Mā'idah: 4 .

Keharusan merujuk pada riwayat sahabat untuk menetapkan legalitas Asbāb al-Nuzūl sebagaimana dikemukakan mayoritas ulama sebenarnya masih mengandung berbagai problem yang harus diselesaikan sehingga validitas riwayat Asbāb al-Nuzūl dapat dipertangungjawabkan. Problematika tersebut antara lain:

D.1. Tidak semua riwayat sahabat (walaupun sahih) yang secara tegas menunjukkan sebab nuzūl ayat, sebagian riwayat hanya 
mengandung kemungkinan adanya sebab. Solusi dalam masalah ini adalah:

D.1.a. Jika perawi mengatakan "sebab turun ayat ini adalah begini", atau dengan menggunakan fa ta'aqubiyah (yang berarti "maka" setelah adanya peristiwa) yang dirangkai dengan "turunlah ayat", sesudah ia menjelaskan peristiwa atau pertanyaan, misalnya: حدث كذا (telah terjadi peristiwa begini) atau سئل رسول الله عن كذا فنزلت الآية (Rasulullah ditanya tentang hal seperti ini, maka turunlah ayat). Redaksi-redaksi di atas secara pasti menunjukkan Asbāb al-Nuzūl. ${ }^{45}$

D.1.b. Jika perawi menggunakan redaksi نزلت هذه الآية في كذا (Ayat ini

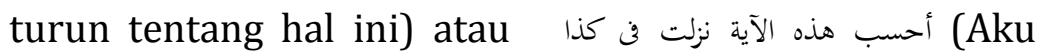
أحسب هذه الآية mengira ayat ini turun mengenai soal ini) atau (Aku tidak mengira ayat ini turun kecuali mengenai hal begini). Redaksi-redaksi di atas mungkin menunjukkan sebab nuzul mungkin yang lain. 46 Terkait dengan hal ini al-Zarkasyi mengatakan: "Telah diketahui dari kebiasaan para sahabat dan tabi'in bahwa apabila salah seorang dari mereka berkata: “ Ayat ini turun mengenai urusan ini", maka yang dimaksud adalah bahwa ayat itu mengandung hukun urusan tersebut; bukannya urusan itu sebagai sebab turunnya ayat. Pendapat sahabat ini termasuk ke dalam jenis penyimpulan hukum dengan ayat, bukan pemberitaan tentang sesuatu kenyataan yang terjadi". ${ }^{47}$

D.2. Adanya berbagai riwayat yang menjelaskan sebab nuzulnya ayat tertentu. Solusi dalam hal ini adalah:

D.2.1. Jika salah satu dari dua riwayat tersebut sahih dan yang lainnya tidak, maka yang dijadikan sebagai Asbāb alNuzūl adalah riwayat yang sahih saja. Hal ini bisa dilihat 
dari dua kasus ini. Pertama, riwayat dari Jundāb berkata: "Nabi Muhammad mengeluh karena sudah satu/dua malam dia tidak bangun. Kemudian seorang perempuan mendatanginya lalu berkata : "Wahai Muhammad, saya tidak melihat setanmu kecuali dia telah meninggalkanmu". Kemudian Allah menurunkan :

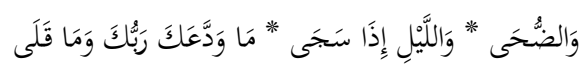

"Demi waktu matahari sepenggalahan naik, dan demi malam apabila telah sunyi (gelap), Tuhanmu tiada meninggalkan kamu dan tiada (pula) benci kepadamu." (QS. al-D \{uhā [93]: 1-3).

Kedua, riwayat dari Hafș bin Muyassarah, dari ibunya yaitu pembantu Rasulullah: "Sesungguhnya seekor anak anjing masuk ke rumah Rasulullah, kemudian masuk ke bawah kasur Rasulullah lalu mati. Rasulullah mendiami rumah selama 4 hari tetapi wahyu tidak turun kepadanya. Kemudian beliau berkata : "Wahai Khaulah apa yang terjadi di rumah Rasulullah? Jibril tidak mendatangiku", kemudian aku berbicara pada diri sendiri. Seandainya engkau menyiapkan rumah dan menyapunya. Kemudian saya membersihkan bawah kasur dengan sapu, lalu saya mengeluarkan bangkai anak anjing itu. Kemudian Rasulullah datang dan jenggotnya bergetar, dan apabila turun (wahyu) kepadanya maka dia bergetar. Kemudian Allah menurunkan : (وَضضُحَى) sampai lafal (فَتَرْضَىَ)."48

D.2.2. Jika ada dua riwayat yang sahih tetapi salah satunya lebih rajih, maka riwayat tersebut yang diambil dengan meninggalkan riwayat lainnya. Kerajihan tersebut dapat dilihat dari 2 hal; Pertama, karena kesahihannya. Kedua, salah satu perawi dari riwayat-riwayat tersebut menyaksikan langsung Asbāb al-Nuzūl dan yang lainnya 
tidak. Contohnya riwayat dari Ibn Mas'ūd berkata : "Saya berjalan bersama Rasulullah di Madinah, kemudian beliau istiharat di atas tulang belakangnya. Lalu lewat serombongan orang Yahudi. Sebagian dari mereka berkata : "Seandainya kalian bertanya kepadanya". Kemudian mereka berkata : "Ceritakan kepada kami tentang ruh". Lalu Nabi berdiri dan mengangkat kepalanya, saya (Ibn Mas'ūd) tahu bahwa dia sedang diberi wahyu. Tatkala wahyu itu selesai, Nabi berkata:

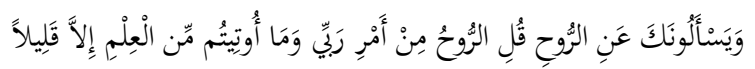

Dan mereka bertanya kepadamu tentang roh. Katakanlah: "Roh itu termasuk urusan Tuhan-ku, dan tidaklah kamu diberi pengetahuan melainkan sedikit" (QS. al-Isrā' [17]: 58).

Dalam riwayat yang lain disebutkan bahwa Ibn Abbas berkata: "Serombongan Quraysh berkata kepada orangorang Yahudi : 'Berikan kepada kami sesuatu dengan bertanya pada laki-laki ini (Muhammad Saw.)'. Kemudian mereka berkata : 'Tanyakan kepadanya tentang ruh" Lalu mereka bertanya kepadanya, dan turunlah ayat di atas.

Riwayat kedua diturunkan di Makkah, Asbāb al-Nuzūlnya adalah pertanyaan Quraiysh kepada Nabi Muhammad; sedangkan riwayat pertama turun di Madinah dengan Asbāb al-Nuzūl berupa pertanyaan Yahudi kepada Rasulullah.

Dalam hal ini riwayat yang paling rājị adalah riwayat pertama, dengan alasan sebagai berikut;

(1). Riwayat pertama diriwayatkan oleh Imām Bukhārī, sedangkan riwayat kedua diriwayatkan oleh Imām Tirmiżī. Sudah dimaklumi bagi ahli hadith bahwa riwayat Imam Bukhari lebih sahih dibanding riwayat Imām Tirmiżī. 
(2). Perawi riwayat yang pertama adalah Ibn Mas'ūd, dan dia menyaksikan proses turunnya ayat tersebut (Asbāb al-Nuzūl-nya) dari awal hingga akhir. Sedangkan riwayat kedua diriwayatkan oleh Ibn 'Abbās. Dalam riwayat tersebut tidak diterangkan bahwa Ibn 'Abbās menyaksikan proses turunnya ayat tersebut dari awal sampai akhir. Maka riwayat yang rawinya mengikuti prosesnya dari awal sampai akhir lebih sahih dibanding riwayat satunya.

D.2.3. Jika ada 2 riwayat $A s b a \bar{b}$ al-Nuzūl yang sama-sama sahih dengan derajat kesahihan yang sama dan masa kejadiannya tidak berjauhan sehingga tidak ada yang lebih rajih antara satu dan lainnya, maka kedua riwayat tersebut digabungkan (الحَمْعُ). Hal ini dapat dilihat dalam Asbāb al-Nuzūl turunnya surat al-Nūr : 6-9. Riwayat pertama: Dari Ikrimah dari Ibn 'Abbas sesungguhnya Hilāl bin Umayah menuduh istrinya berzina dengan Syārik bin Sahamah di depan Rasulullah. Kemudian dia berkata kepada Nabi, "Tunjukkan bukti atau penggungmu dikenai hād (hukuman)." Dia menjawab, "Wahai Rasulullah! Apakah perlu kita menunjukkan bukti apabila ada istri salah seorang diantara kita bersama laki-laki lain." Dalam riwayat lain dikatakan, "Demi Allah saya jujur, ya Allah turunkanlah (wahyu) yang bisa membebaskan punggungku dari hăd. Kemudian turunlah surat al-Nūr : 6-9.

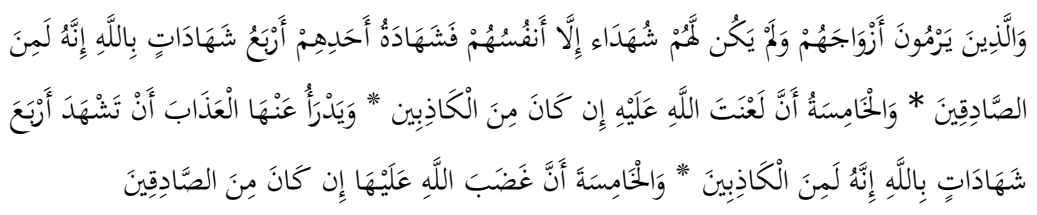


Dan orang-orang yang menuduh isterinya (berzina), padahal mereka tidak mempunyai saksi-saksi selain diri mereka sendiri, maka persaksian orang itu ialah empat kali bersumpah dengan nama Allah, sesungguhnya dia adalah termasuk orang-orang yang benar. Dan (sumpah) yang kelima: bahwa la'nat Allah atasnya, jika dia termasuk orang-orang yang berdusta Istrinya itu dihindarkan dari hukuman oleh sumpahnya empat kali atas nama Allah sesungguhnya suaminya itu benarbenar termasuk orang-orang yang dusta. dan (sumpah) yang kelima: bahwa laknat Allah atasnya jika suaminya itu termasuk orangorang yang benar. (QS. al-Nur [24]: 6-9).

Riwayat kedua: Dari Sahal bin Sa'ad sesungguhnya Uwaimir mendatangi 'Āṣim bin 'Adi, dia adalah pemuka bani 'Ajlan. Kemudian dia berkata, "Apa yang akan kalian katakan pada seorang laki-laki yang mendapati istrinya bersama laki-laki lain, apakah kamu akan menyuruh membunuhnya atau kalian yang akan membunuhnya, atau apa yang harus dilakukan?" "Tanyakan kepada Rasulullah tentang hal itu." Kemudian 'Āṣim datang kepada Rasulullah lalu bertanya kepadanya, "Wahai Rasulullah!" Dalam riwayat lain dikatakan bahwa 'Āṣim bertanya kepada Rasulullah tetapi Rasulullah tidak menyukai masalah itu kemudian beliau tidak menghiraukannya." Kemudian Uwaimir berkata, "Saya tidak akan berhenti sebelum menanyakan hal ini kepada Rasulullah." Kemudian Uwaimir datang dan berkata, "Wahai Rasulullah! Ada seseorang yang mendapatkan istrinya bersama laki-laki lain, haruskah dia 
membunuhnya atau kalian yang akan membunuhnya, atau apa yang harus dilakukan." Lalu Rasulullah berkata, "Sungguh Allah telah menurunkan ayat mengenai permasalahanmu dan sahabatmu itu (yakni QS. al-Nūr [24]: 6-9). Kemudian Rasulullah memerintahkan kepada keduanya untuk melaknatnya (istri tersebut) dengan nama-nama Allah dalam kitab-Nya. Kemudian beliau melaknatnya.

D.2.4. Jika ada dua riwayat yang sama-sama sahih tetapi tidak

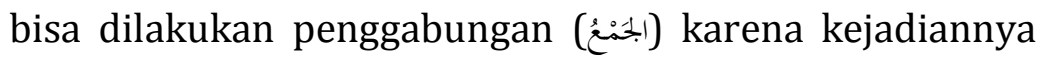
yang berjauhan, maka kedua riwayat tersebut diambil semuanya tanpa menghilangkan yang lain. Adapun contohnya, riwayat pertama diriwayatkan oleh al-Baihaqī dan al-Bazzar, dari Abū Hurairah sesungguhnya Rasulullah bersikap terhadap kesyahidan Hamzah kemudian beliau membuat permisalan tentangnya. Dia berkata, "Sesungguhnya kedudukanmu bagaikan kedudukan 70 syahid yang lain". Kemudian Jibril turun membawa wahyu 3 ayat terakhir surat al-Nahl.

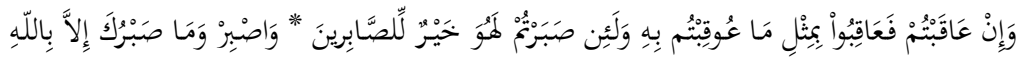

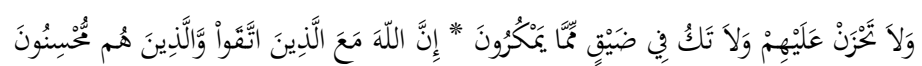

Dan jika kamu memberikan balasan, maka balaslah dengan balasan yang sama dengan siksaan yang ditimpakan kepadamu. Akan tetapi jika kamu bersabar, sesungguhnya itulah yang lebih baik bagi orang-orang yang sabar. Bersabarlah (hai Muhammad) dan tiadalah kesabaranmu itu melainkan dengan pertolongan Allah dan janganlah kamu bersedih hati terhadap (kekafiran) mereka dan janganlah kamu bersempit dada terhadap apa yang mereka tipu dayakan. Sesungguhnya Allah beserta orang-orang yang bertakwa dan orang-orang yang berbuat kebaikan (QS. al-Naḥl [16]: 126-128). 
Riwayat kedua, diriwayatkan oleh Tirmiżī dan Ḥākim, dari 'Ubay bin Ka'ab berkata, "Ketika terjadi perang Uhud ada 64 korban dari Anșār dan 6 korban dari Muhājirīn, di antaranya Hamzah. Kemudian mereka memberi permisalan baginya, lalu golongan Anșār berkata, "Jika suatu hari menjadi korban seperti mereka, sungguh kami akan menambah (jumlah) orang yang syahid." Ketika terjadi Fath al-Makkah, Allah menurunkan 3 ayat di atas. Pada riwayat pertama, ditunjukkan bahwa ayat tersebut turun sesudah terjadinya perang Uhud, sedangkan riwayat kedua menunjukkan bahwa ayat tersebut turun ketika terjadi Fath al-Makkah. Sementara jarak antara perang Uhud dan Fath al-Makkah mencapai beberapa tahun. Sehingga tidak mungkin dilakukan penggabungan terhadap dua riwayat tersebut. Oleh karena itu, kedua riwayat tersebut dapat dipakai semuanya.

Riwayat ketiga, adanya beberapa ayat al-Quran yang diturunkan karena satu sebab. Solusi dalam hal ini adalah diterimanya riwayat tersebut jika memang Shahih (valid). Contoh dalam hal ini adalah riwayat pertama Ibn Jarīr al-Ṭabarī, Ṭabrānī dan Ibn Mardawiyah, meriwayatkan dari Ibn 'Abbas berkata, "Rasulullah duduk di bawah naungan pohon, kemudian beliau berkata, "Akan datang kepada kalian manusia yang menatap dengan tatapan setan, apabila dia datang maka jangan berbicara dengannya." Tidak lama kemudian muncullah seorang laki-laki dengan dua mata berwarna biru. Kemudian Rasulullah saw memanggilnya dan berkata, "Untuk apa kamu dan teman-temanmu mengutukku?" Kemudian laki-laki itu pergi dan datang lagi dengan membawa sahabat-sahabatnya. Lalu mereka 
bersumpah dengan nama Allah hingga berlebihan dalam sumpahnya. Kemudian Allah menurunkan

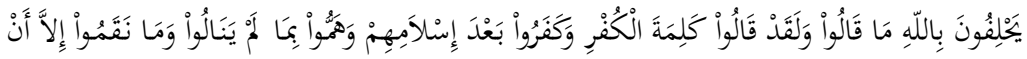

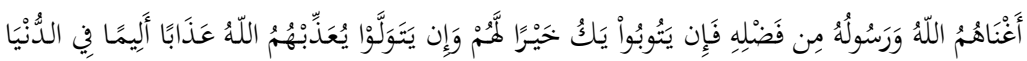

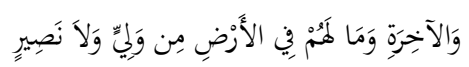

Mereka (orang-orang munafik itu) bersumpah dengan (nama) Allah, bahwa mereka tidak mengatakan (sesuatu yang menyakitimu). Sesungguhnya mereka telah mengucapkan perkataan kekafiran, dan telah menjadi kafir sesudah Islam dan mengingini apa yang mereka tidak dapat mencapainya, dan mereka tidak mencela (Allah dan Rasul-Nya), kecuali karena Allah dan RasulNya telah melimpahkan karunia-Nya kepada mereka. Maka jika mereka bertaubat, itu adalah lebih baik bagi mereka, dan jika mereka berpaling, niscaya Allah akan mengazab mereka dengan azab yang pedih di dunia dan akhirat; dan mereka sekali-kali tidaklah mempunyai pelindung dan tidak (pula) penolong di muka bumi. (QS. al-Taubah [9]: 74).

Hadis di atas juga diriwayatkan oleh Hākim dan Ahmad, tetapi riwayat tersebut menjadi sebab nuzūl-nya surat alMujādilah [58]: 18-19.

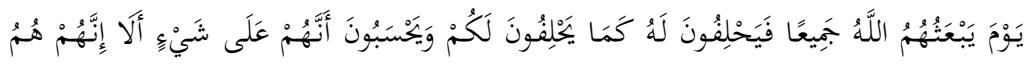

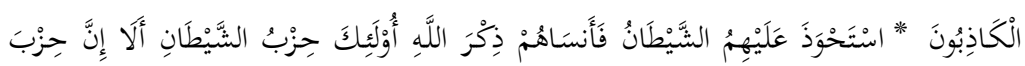

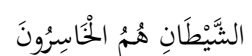

(Ingatlah) hari (ketika) mereka semua dibangkitkan Alla) lalu mereka bersumpah kepada-Nya (bahwa mereka bukan musyrikin) sebagaimana mereka bersumpah kepadamu; dan mereka menyangka bahwa mereka akan memperoleh suatu (manfaat). Ketahuilah, bahwa 
sesungguhnya merekalah orang-orang pendusta. Setan telah menguasai mereka lalu menjadikan mereka lupa mengingat Allah; mereka itulah golongan syaitan. Ketahuilah, bahwa sesungguhnya golongan syaitan itulah golongan yang merugi. ${ }^{49}$

Kedua ayat di atas turun karena kejadian yang sama sebagaimana riwayat-riwayat di atas.

\section{E. Penutup}

Berdasarkan uraian di atas, urgensi Asbāb al-Nuzūl adalah: mengetahui hikmah turunnya ayat al-Quran, mempermudah memahami ayat al-Quran, menghindari kesamaran al-Hasyr, (batasan) hukum dengan sabab yang terjadi, menggunakan Asbāb al-Nuzūl dalam takhṣiș, , mengetahui dengan jelas nama orang terkait Asbāb al-Nuzūl sebuah ayat, Mempermudah menghafal dan mengokohkan hati pendengar ayat al-Quran

Legalitas Asbāb al-Nuzūl ditetapkan dengan periwayatan hadis dan ijtihad. Penetapan riwayat Asbāb al-Nuzūl didasarkan pada redaksi yang jelas menunjukkan sebab nuzūl, sementara redaksi yang tidak tegas diasumsikan adanya sebab dan kandungan hukum. Solusi terkait dengan adanya berbagai riwayat yang menjadi sebab turunnya ayat tertentu adalah:

1. Apabila ada dua riwayat yang berbeda, maka dipegangi yang riwayatnya lebih valid.

2. Apabila sanad dari dua riwayat sama validnya, maka keduanya digabungkan selama tidak dapat ditarjih dan peristiwanya tidak berselang lama.

3. Apabila sanad dari dua riwayat sama validnya, maka diutamakan adalah perawi yang menyaksikan peristiwa atau pertimbangan-pertimbangan semacamnya (ditarjih)

4. Apabila dua riwayat tersebut sulit ditarjih, maka pemecahannya adalah hipotesis berulang-ulangnya turun 
ayat setelah ada dua sebab atau sebab-sebab yang disebutkan

Terhadap adanya suatu peristiwa yang kemudian menjadi sebab turunnya beberapa ayat al-Quran, maka peristiwa tersebut menjadi legalitas beberapa ayat yang turun tersebut. []

\section{DAFTAR PUSTAKA}

Abū Syahbah, Muḥammad, al-Madkhal li Dirāsah al-Qur'ān, Beirūt: Dār al-Jail, 1992.

Abū Zayd, Nasr Ḥāmid, Tektualitas al-Quran, terj. Khoiron Nahdhiyyin, Yogyakarya: LKis, 2002.

'Arabiyah, Mujamma' al-Lughah, al-Mu'jam al-Wasit, Kairo: Maktabah al-Shurūq al-Dawliyah, 11425/2004.

Aththar, Dawud, Perspektif Baru Ilmu al-Quran, Bandung: Pustaka Hidayah, 1994.

Bukhārī, Muḥammad ibn Ismā'īl, Șaḥịh al-Bukhārī, Juz III, Beirūt: Dār al-Fikr, t.th.

Khalafullah, Muhammad A., al-Quran Bukan Kitab Sejarah Seni, Sastra dan Moralitas dalam Kisah-Kisah al-Quran, terj. A. Kholil, Jakarta: Paramadina, 2002.

Ma'luf, Louis, al-Minjid fi al-Lughah wa al-A'lām, Beirūt: Dār alFikr, 1984.

Munawwir, Ahmad Warson, Kamus al-Munawwir, Yogyakarta: Pustaka Progresif, 1997.

Namīr, 'Abd al-Mu'īn, 'Ulūm al-Qur'ān al-Karīm, Beirūt: Dār alKutub al-Labnanī, 1983.

Qaț̣ān, Manna' Khalīl, Mabāḥiś fì 'Ulūm al-Qur'ān, Beirūt: Mansyūrāt al-'Așr al-Ḥadīs, t.th. 
Șabūnī, 'Alī, al-Tibyān fī 'Ulūm al-Qur'ān, Beirūt: Dār al-Kutub alIslāmī, 2003.

Șāliḥ, Șubḥī, Mabāḥiś fí 'Ulūm al-Qur'ān, Beirūt: Dār 'Ilmi li al-Malāyīn, 1988.

Syāțibī, al-Muwāfaqat fì Ușūl al-Syarīah, Kairo: Dār al-Kutub al'Arabī, t.th.

Suyūṭi, 'Abd al-Raḥmān Jalāl al-Dīn, al-Itqān fì 'Ulūm al-Qur'ān, jil. I, Beirūt: Dār al-Fikr, 1978.

Suyūṭi, 'Abd al-Raḥmān Jalāl al-Dīn, Lubāb al-Nuqūl fì Asbāb alNuzūl, Kairo : Dār al-Taqwā, 2004.

Taymiyah, Ibn, Muqaddimah fí Ușūl al-Tafsīr, Kuwait: Dār alQur'ān al-Karīm, 1971.

Wāḥidī, Abū al-Ḥusain 'Alī bin Aḥmad, Asbāb al-Nuzūl, Kairo: Dār al-Ḥadìs, 2003.

Zarqānī, 'Abd al-'Azịm, Manāhij al-'Irfān fì 'Ulūm al-Qur'ān, juz I, Beirūt: Dār al-Fikr, tth.

\section{Catatan Akhir}

${ }^{1}$ Muhammad Abū Syahbah, al-Madkhal li Dirāsah al-Qur'ān, Beirūt: Dār al-Jail, 1992, h. 122.

2Nasr Ḥāmid Abū Zayd, Tektualitas al-Quran, terj. Khoiron Nahdhiyyin, Yogyakarya: LKiS, 2002, h. 115.

3Manna' Khalīl al-Qațtān, Mabāhisis fi 'Ulūm al-Qur'ān, Beirūt: Mansyūrāt al-'Așr al-Hadīs̀, t.th, h. 78.

${ }^{4}$ Muhammad A. Khalafullah, al-Quran Bukan Kitab Sejarah Seni, Sastra dan Moralitas dalam isah-Kisah al-Quran, terj. A. Kholil, Jakarta: Paramadina, 2002, h. 25.

5Lih.: Mujamma' al-Lughah al-'Arabiyah (Jumhūriyah Mișr al'Arabiyah), al-Mu'jam al-Wasiț, Kairo: Maktabah al-Shurūq alDawliyah, 1425/2004, h. 411.

${ }^{6} \mathrm{Abū}$ al-H\{usain 'Alī bin Aḥmad al-Wahīì̄, Asbāb al-Nuzūl, Kairo: Dār al-H adīṡah, 2003, h. 5. 
7Mujamma', al-Mu'jam, h. 411.

8Louis Ma'lūf, al-Munjid fì al-Lughah wa al-A'lām, Beirūt: Dār alFikr, 1984, h. 802. Bandingkan dengan Ahmad Warson Munawwir, Kamus al-Munawwir, Yogyakarta: Pustaka Progresif, 1997, h. 1408.

${ }^{9}$ al-Wāhidī, Asbāb, h. 6.

10 Șubhị Ṣāliḥ, Mabāhịis fí 'Ulūm al-Qur'ān, Beirūt: Dār 'Ilmi li al-Malāyin, 1988, h. 132.

11al-Suyūṭi, al-Itqān, jil. I, h. 29.

12'Abd al-'Az̄ìm al-Zarqanī, Manāhi al-'Irfān fì 'Ulūm al-Qur'ān, juz I, Beirūt: Dār al-Fikr, t.th, h. 106.

${ }^{13}$ Contoh peristiwa ini adalah adanya perselisihan yang terjadi antara suku al-Aus dan al-Khazraj yang hampir saja menimbulkan peperangan diantara keduanya. Atas peristiwa ini maka turunlah ayat 100-103 surat Ali ‘Imrān. Lebih jelasnya al-Wahīdī, Asbāb, h. 111.

14 Contoh peristiwa ini adalah adanya seseorang yang mabuk yang menjadi imam shalat yang kemudian salah dalam membaca surat al-kafirun. Atas peristiwa ini maka turun ayat 43 surat al-Nisa'

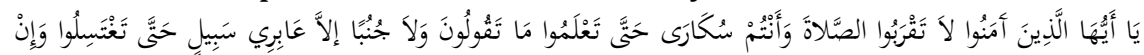

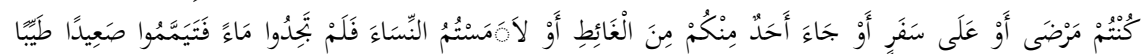

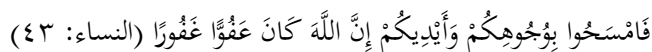

Lih.: al-Wāhidī̄, $A s b \bar{a} b$, h. 146.

${ }^{15}$ Bukhārī meriwayatkan dari Anas bahwa 'Umar berkata: "Saya punya keinginan yang kemudian sesuai dengan keinginan Allah. Pertama, Saya bertanya kepada Rasulullah: "Ya Rasulullah alangkah baiknya jika kita menjadikan maqām Ibrāhīm sebagai tempat salat", maka Allah menurunkan surat al-Baqarah ayat 125. Kedua, Aku bertanya kepada nabi: "Ya Rasulullah, orang-orang yang datang kepada isterimu ada yang baik dan ada yang buruk, seyogyanya engkau menyuruh mereka untuk memakai hijab, maka turunlah ayat hijab surat al-Ahzāb ayat 53:

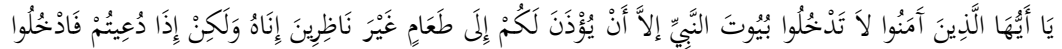

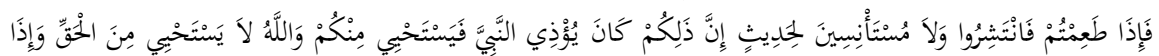

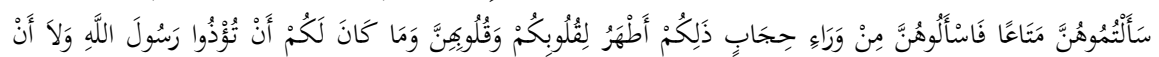

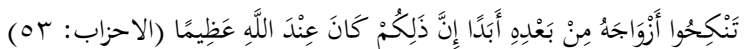

Ketiga, ketika isteri-isteri nabi cemburu maka aku berkata kepada mereka: "Semoga Allah menceraikan engkau semua dan mengganti nabi isteri-isteri yang lebih baik", maka Allah menurunkan surat al-Tahrim ayat 5 


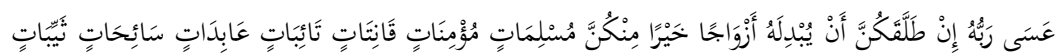

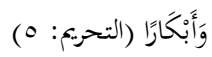

Lebih jelasnya lihat al-Bukhārī, Șahīḥ al-Bukhārī, juz III, Beirūt: Dār al-Fikr, t.th, h. 99.

${ }^{16}$ Contohnya sebagaimana sebab turunya ayat 83 surat al-Kahfi tentang Żū al-Qarnain. Lih.: al-Wāhịidī, Asbāb, h. 307.

17 Contohnya seperti turunya surat al-Isra' ayat 85 tentang Ruh.

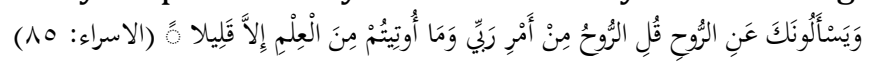

Lih.: al-Wāhidì, Asbāb, h. 299.

${ }^{18}$ Contohnya turunnya surat al-A'rāf ayat 187

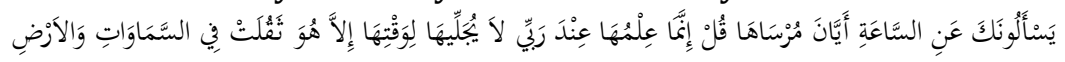

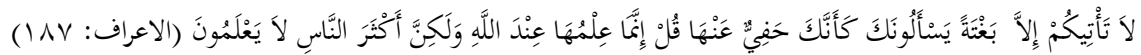

Lih.: al-Wāhidīi, Asbāb, h. 224.

${ }^{19}$ Contohnya pertanyaan Khaulah bin al-Tha'labah kepada nabi tentang hukumnya zihar yang dilakukan suaminya Aus bin Șāmid terhadapnya. Atas pertanyaan ini maka turunlah surat al-Mujādilah: 14. Lih.: al-Wāhidì̄, Asbāb, h. 433.

${ }^{20}$ Demikian juga dengan hadīs al-Ifq (cerita tuduhan perselingkuhan 'Aishah isteri Nabi) turun setelah satu bulan. Lih.: Abū Shahbah, al-Madkhal, h. 123. Bandingkan dengan Bukhārī, Șahịḥ̣, jil. III, h. 163-166.

${ }^{21}$ Lih.: al-Wāhịid̄̄, $A s b a \bar{b} b$, h. 500.

22al-Suyūțī, al-Itq>an fi 'Ulūm al-Qur'ān, jil, I, Beirūt: Dār al-Fikr, 1978, h. 88. al- al-Suyūṭī juga mengutip pendapat Ibn Daqīq al-'Id yang mengatakan:

$$
\text { بيان سباب النزول طريق قوي ف فهم معانى القرآن }
$$

"Keterangan sabāb al-nuzūl adalah cara yang kuat (tepat) untuk memahami makna al-Quran." Bandingkan dengan al-Suyūțī, Lubāb alNuqūl fi Asbāb al-Nuzūl, Kairo : Dār al-Taqwā, 2004, h. 5.

23Ibn Taymiyah, Muqaddimah fi Ușūl al-Tafsīr, Kuwait: Dār alQur'ān al-Karīm, 1971, h. 47-48.

24 al-Wāhịidī, Asbāb, h. 12

${ }^{25}$ Sebagai contoh, kata Istifhām dalam bahasa Arab memiliki beberapa arti, seperti "menetapkan kebaikan" ( تَحْرِيرِ ) atau "cercaan" (

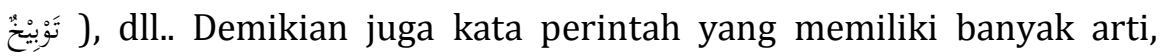

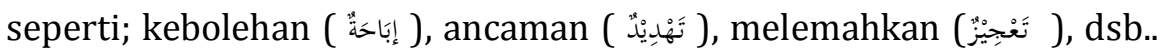
Arti kata-kata tersebut hanya bisa ditemukan jika indikator-indikator 
yang menunjukkan maknanya atau keadaan dimana kata-kata itu muncul diketahui. Artinya, bagi ayat yang memiliki Asbāb al-Nuzūl, maka keadaan dimana kata-kata itu muncul harus diketahui. Jika ayat tersebut tidak memiliki Asbāb al-Nuzūl, maka dalam mengartikan ayat al-Quran harus memperhatikan indikator-indikatornya. Tanpa salah satu dari dua hal ini, maka penafsiran tersebut dapat dianggap cacat. Lih.: al-Wāḥidī, Asbāb, h. 6 Bandingkan dengan Dawud al-al-Aththar, Perspektif Baru Ilmu al-Quran, Bandung: Pustaka Hidayah, 1994, h. 130.

26 Contohnya adalah riwayat Abū 'Ubaid dari Ibrāhīm al-Taimī berkata : "Pada suatu hari, Umar berbicara pada dirinya sendiri: 'Apa yang menyebabkan umat Islam berselisih, padahal umat ini memiliki satu Nabi, satu agama dan satu kiblat?' Kemudian Ibn Abbas berkata: 'Wahai Amir al-Mu'minin, sesungguhnya al-Quran telah diturunkan kepada kita, kemudian kita membacanya (mempelajarinya), sesudah itu kita mengajarkan dalam keadaan apa al-Quran itu turun (Asbāb alNuzūl). Sesungguhnya pada suatu masa sesudah kita akan ada beberapa kaum yang membaca al-Quran tetapi tidak mengetahui dalam keadaan apa al-Quran itu turun. Kemudian munculah pendapat/tafsiran mereka mengenai al-Quran. Di saat muncul pendapat itulah mereka mulai berselisih, setelah berselisih mereka akan saling berperang." Ibrahim berkata :"Kemudian Umar geram (menahan marah) kepada Ibn Abbas sehingga Ibn 'Abbās berpaling Kemudian Umar kembali memikirkan apa yang dikatakan Ibn Abbas. Kemudian ia memahami dan menyetujuinya. Lalu Umar berkata: 'Ulangilah apa yang kamu katakan tadi kepadaku” kemudian Ibn Abbas mengulanginya hingga Umar paham dan takjub dengan perkataannya " (lih.: al-Wahīdī, Asbāb, h. 7). Bandingkan dengan alSyātibī, al-Muwāfaqāt fì Ușūl al-Sharī'ah, Kairo: Dār al-Kutub al-'Arabī, t.th, h. 76.

27al-Suyūțī, al-Itqān, jil. I, h. 29-31. Bandingkan dengan alBukhārī, Saḥịh, jil. III, h. 115.

28 al-Zarqani, Manahi, 109. Bandingkan dengan 'Alī al-Ṣabūnī, alTibyān fì 'Ulūm al-Qur'ān, Beirūt: Dār al-Kutub al-Islāmī, 2003, h. 20.

${ }^{29}$ Dari Abū Hurairah berkata: Rasulullah mendatangi Madinah, sedangkan penduduknya pada waktu itu suka minum khamr dan berjudi. Kemudian mereka bertanya kepada Rasulullah tentang kedua kebiasaan mereka itu. Kemudian Allah menurunkan:

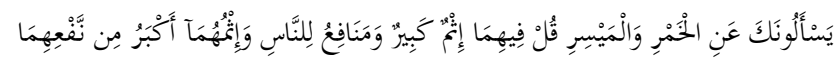


"Mereka bertanya kepadamu tentang khamar dan judi. Katakanlah: "Pada keduanya terdapat dosa yang besar dan beberapa manfaat bagi manusia, tetapi dosa keduanya lebih besar dari manfaatnya."...(QS. al-Baqarah [2]: 219) .

Mereka berkata: (kedua hal itu) tidak diharamkan pada kita. Kemudian mereka melanjutkan perkataannya: hanya sebatas dosa besar saja. Kemudian mereka tetap meminum khamr hingga suatu hari ada seorang muhajirin yang shalat mengimami para sahabat kemudian bacaannya rancu. Kemudian Allah menurunkan ayat yang lebih tegas (akan kemadharatan khamr) dari sebelumnya,

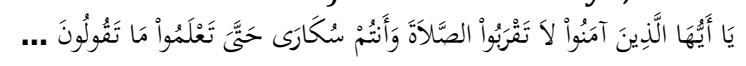

"Hai orang-orang yang beriman, janganlah kamu shalat, sedang kamu dalam keadaan mabuk, sehingga kamu mengerti apa yang kamu ucapkan..."(QS. al-Nisā' [4]: 43).

Kemudian turun lagi ayat yang lebih tegas lagi (menjelaskan bahwa khamr itu haram):

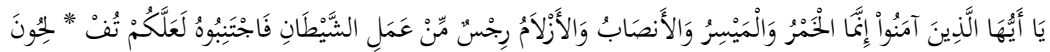

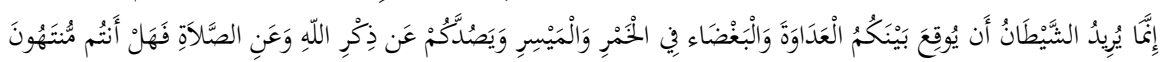

“Hai orang-orang yang beriman, sesungguhnya (meminum) khamar, berjudi, (berkorban untuk) berhala, mengundi nasib dengan panah, adalah termasuk perbuatan syaitan. Maka jauhilah perbuatanperbuatan itu agar kamu mendapat keberuntungan. Sesungguhnya syaitan itu bermaksud hendak menimbulkan permusuhan dan kebencian di antara kamu lantaran (meminum) khamar dan berjudi itu, dan menghalangi kamu dari mengingat Allah dan sembahyang; maka berhentilah kamu (dari mengerjakan pekerjaan itu) (QS. alMā'idah [5]: 90-91). Lih.: al-Suyūțī, Lubāb, h. 9.

30Diriwayatkan dari 'Uṡmān ibn Maẓ'ūn dan 'Amr ibn Makdikariba bahwa keduanya mengatakan bahwa khamr adalah halal, keduanya berhujjah dengan surat al-Mā'idah [5]: 93,

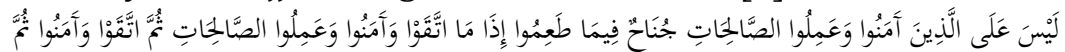

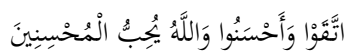

"Tidak ada dosa bagi orang-orang yang beriman dan mengerjakan amalan yang saleh Karena memakan makanan yang Telah mereka makan dahulu, apabila mereka bertakwa serta beriman, dan mengerjakan amalan-amalan yang saleh, Kemudian mereka tetap bertakwa dan beriman, Kemudian mereka (tetap juga) bertakwa dan 
berbuat kebajikan. dan Allah menyukai orang-orang yang berbuat kebajikan."

Keduanya tidak memahami ayat ini dengan benar, sebab ayat ini turun terkait dengan petanyaan tentang para sahabat yang telah meninggal dunia sedang mereka telah minum khamr lalu turun ayat ini. Lih.: al-Suyūțī, al-Itqān, jil. I, h. 88; juga 'Abd al-Mu'im al-Namīr, 'Ulūm al-Qur'ān, h. 97-98.

${ }^{31}$ al-Hasyr adalah menetapkan hukum yang disebutkan dan meniadakan hukum selainnya. Lafal ini juga dapat disebut al-qașr (Mujamma' al-Lughah, al-Mu'jam, h. 176.

${ }^{32}$ Artinya, makanan haram itu tidak hanya yang dsebutkan dalam ayat tersebut, sedangkan yang lainnya halal.

33 al-Zarqani, Manahi, jil. I, h. 112.

34 al-Suyūțī, al-Itqān, jil. I, h. 89.

35 al-Zarqan̄i, Manāhi, jil. I, 113.

36 al-Bukhari, Șahīḥ, jil. II, h. 3-4; ilihat pula al-Zarqanī, Manāhij, jil. I,h. 113.

${ }^{37} \mathrm{Al}$-Bukhārī meriwayatkan hadis tentang perintah Mu'āwiyah kepada Marwān agar mengajak orang-orang bai'at kepada Yazīd anak Mu'āwiyah, namun hal tersebut ditolak oleh 'Abd al-Raḥmān bin Abū Bakar hingga Marwān menyuruh menangkapnya, namun 'Abd alRaḥmān bin Abū Bakar masuk ke rumah 'Aishah sehingga Marwan tidak bisa menangkapnya. Kemudian Marwan berkata: "inilah yang dimaksud dengan firman Allah:

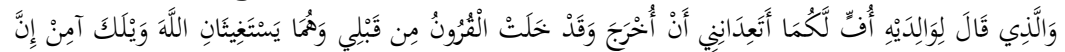

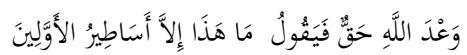

"Dan orang yang Berkata kepada dua orang ibu bapaknya: "Cis bagi kamu keduanya, apakah kamu keduanya memperingatkan kepadaku bahwa Aku akan dibangkitkan, padahal sungguh Telah berlalu beberapa umat sebelumku? lalu kedua ibu bapaknya itu memohon pertolongan kepada Allah seraya mengatakan: "Celaka kamu, berimanlah! Sesungguhnya janji Allah adalah benar". lalu dia berkata: "Ini tidak lain hanyalah dongengan orang-orang dahulu belaka." (QS. al-Ahqā̄f [46]: 17).

Kemudian dibalik hijab 'Aishah menjawab: "Allah tidak pernah menurunkan ayat al-Quran tentang kasus orang tertentu diantara kita kecuali ayat yang menurunkan tentang uzurku (kebebasanku)." Lihat al-Bukhārī, Sahīh , jil. III, h. 188.

38 al-Zarqanī, Manāhi, jil. I,115. 
39 Muḥammad Bakar, Dirāsāt, h. 176; 'Ali al-Ṣabūnī, al-Tibyān, h. 25.

40 Ibid.,h. 114.

41 Ibid., h. 102.

42 Tingkatannya dianggap sama dengan hadis yang disandarkan kepada Rasulullah saw.

43 Ibid., h. 102; dan lihat juga 'Abd al-Raḥmān bin Abī Bakar alSuyūṭì, Lubāb, h. 8.

${ }^{44}$ Contoh yang dikemukakan Nasr dalam hal ini adalah pembacaan Abū 'Ubaidah tentang surat al-Isrā' ayat 16:

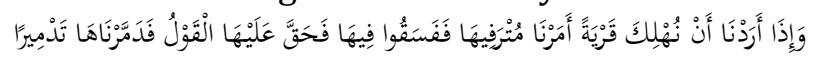

firman Allah: "Apabila Kami ingin menghancurkan sebuah negeri maka Kami memperbanyak orang-orang zalim di dalamnya, kemudian mereka berbuat keji sehingga mereka berhak mendapatkanm keputusan siksa, lalu Kami membinasakannya"; dalam hal ini Abū 'Ubaidah membaca kata kerja "amara" dengan bentuk wazan "af ala" (menjadi (amara). Kata kerja ini berasal dari tiga huruf yang berwazan "amira" dengan arti bertambah. Pembacaan ini dilakukan untuk menghindari pengertian bahwa Allah memerintahkan perbuatan jahat, maksudnya untuk menghindari lahiriah teks. Dari konteks ayat, sangat jelas bahwa ayat tersebut muncul sebagai ancaman. Kata qaryah disebutkan dalam ayat ini menunjuk ancaman pada penduduk Makkah. Konteks ancaman mensyaratkan adanya penegasan kekuasaan. Di balik ayat ini sama sekali tidak terdapat masalah filosofi tentang predestination dan free will. Lihat Nasr, Tekstualitas, h. 131.

45 Contoh hal ini adalah riwayat Bukhari dari Ibn Umar yang berkata: " Nisa'ukum harśun lakum (al-Baqarah [2]: 223) turun terkait dengan menggauli isteri dari jalan belakang/dubur).

46 Contoh dalam hal ini adalah riwayat Ibnu zubair yang mengajukan gugatan kepada seorang lelaki dari kaum Anshor yang pernah ikut perang Badar bersama Nabi, Dihadapan Rasulullah laki Ibnu Zubair menuntut laki-laki tadi tentang saluran air yang mengalir dari tempat yang tinggi; keduanya mengairi kebun kurma masingmasing-masing dari situ. Lakui-laki Anshor berkata: "Biarkan airnya mengalir" tetapi Ibnu Zubair menolak. Maka Rasulullah bersabda: "Ya Zubair airi kebunmu kemudian biarkan air itu mengalir ke kebun tetanggamu" laki-laki Anșār itu marah seraya berkata: "Ya Rasul apa sudah waktunya anak bibimu itu berbuat demikian" wajagh Rasulullah 
kemudian merah seraya berkata: "airi kebunmu Ya Zubair kemudian tahanlah air itu hingga memenuhi pematang; lalu biarkan ia mengalir ke kebun tetanggamu". Dengan ini Rasulullah telah memenuhi hak Zubair yang mana sebelumnya memberi kelonggaran kepada laki-laki anshor tadi. Ketika itu Zubair berkata: Aku tidak mengira ayat berikut ini turun kecuali tentang urusan tersebut, yaitu:

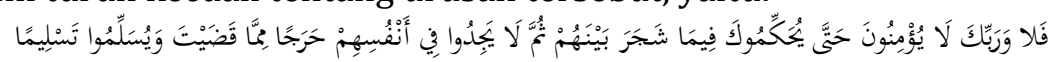

"Maka demi Tuhanmu, mereka (pada hakekatnya) tidak beriman hingga mereka menjadikan kamu hakim terhadap perkara yang mereka perselisihkan, Kemudian mereka tidak merasa dalam hati mereka sesuatu keberatan terhadap putusan yang kamu berikan, dan mereka menerima dengan sepenuhnya." (QS. al-Nisā' [4]: 65).

Lih.: Muhammad Bakar, Dirasat, h. 177; Manna', Mabāḥiś, h. 85. 47 Ibid.

48 al-Zarqāni, Manāhij, h. 117.

${ }^{49}$ Al-Zarqani, Manahi, h. 121-122. 